\title{
Altered Gene Expression Profiles in Mouse Tetraploid Blastocysts
}

\author{
Mi-Ryung PARK ${ }^{1)^{*}}$, Kyu-Chan HWANG ${ }^{1)^{*}}$, Hong-Thuy BUI ${ }^{1)}$, Ssang-Goo $\mathrm{CHO}^{1)}$, Chankyu PARK ${ }^{1)}$, \\ Hyuk SONG ${ }^{2)}$, Jae-Wook $\mathrm{OH}^{3)}$ and Jin-Hoi KIM ${ }^{1)}$ \\ 1) Department of Animal Biotechnology, College of Animal Bioscience and Technology, Konkuk University, Seoul 143-701, \\ Republic of Korea \\ 2) Department of Animal Science, College of Natural Science, Konkuk University, Chung-ju 380-701, Republic of Korea \\ 3) Division of Animal Life Science, College of Animal Bioscience \& Technology, Konkuk University, Seoul 143-701, Republic \\ of Korea
}

\begin{abstract}
In this study, it was demonstrated that tetraploid-derived blastocyst embryos had very few Oct4-positive cells at the mid-blastocyst stage and that the inner cell mass at biomarkers Oct4, Sox 2 and Klf4 was expressed at less than 10\% of the level observed in diploid blastocysts. In contrast, trophectoderm-related gene transcripts showed an approximately 10 to $40 \%$ increase. Of 32,996 individual mouse genes evaluated by microarray, 50 genes were differentially expressed between tetraploid or diploid and parthenote embryos at the blastocyst stage $(\mathrm{P}<0.05)$. Of these 50 genes, 28 were more highly expressed in tetraploid-derived blastocysts, whereas 22 were more highly downregulated. However, some genes involved in receptor activity, cell adhesion molecule, calcium ion binding, protein biosynthesis, redox processes, transport, and transcription showed a significant decrease or increase in gene expression in the tetraploid-derived blastocyst embryos. Thus, microarray analysis can be used as a tool to screen for underlying defects responsible for the development of tetraploid-derived embryos.
\end{abstract}

Key words: Gene expression, Mouse, Tetraploid embryo

(J. Reprod. Dev. 58: 344-352, 2012)

$\mathbf{T}$ etraploid embryos are commonly used to rescue embryonic lethality as a result of defective extra-embryonic phenotypes in laboratory mouse strains, as well as a method for generating mice directly from embryonic stem (ES) cells [1]. Even though spontaneous embryonic tetraploidy is rare [2-4], there are several methods of inducing tetraploidy. The first method is to surgically add a diploid (2n) nucleus to a zygote $[5,6]$. The second method is the use of chemicals or heat-shock to inhibit cleavage. Initially, cytochalasin $\mathrm{B}(\mathrm{CB})$, a microtubule destabilizer, was used as the inhibitor [7-9]. The third method is to fuse 2 diploid embryonic cells. Currently, the most commonly used method for producing tetraploid embryos is electrofusion by electrical stimulation, a technique first developed for the fusion of plant protoplasts [10]. The successful use of this technique was first demonstrated in mice and rats [11, 12]. While adequately demonstrating blastomere fusion, tetraploid mammalian embryos produced by electrofusion were not proven to be capable of subsequent in vitro development until work was performed later on rabbit embryos [13, 14].

Tetraploid embryos are not independently capable of completing normal development $[2,15]$, but when complemented by the introduction of ES cells, they develop into conceptuses in which embryonic lineages are derived entirely from the ES cells and

Received: August 12, 2011

Accepted: February 2, 2012

Published online in J-STAGE: February 24, 2012

(C)2012 by the Society for Reproduction and Development

Correspondence: JH Kim (e-mail: jhkim541@konkuk.ac.kr)

*MR Park and KC Hwang contributed equally to this work. extraembryonic lineages arise largely from the $4 \mathrm{n}$ component $[2$, 16]. This method is known as $4 \mathrm{n}$ embryo complementation. Mice derived from ES cells show normal phenotype, growth and fertility, indicating that ES mice can be used as founders for establishing new lines of mice. Because all germ cells in ES mice are derived from ES cells, germline transmission of ES cells is easier in ES mice than in $2 \mathrm{n}$ chimeric mice [17].

Even though the trophectoderm (TE) and inner cell mass (ICM) grow within the same environment in the blastocyst and have the same genome, they have very different developmental fates. The first cell lineage specification in mouse embryo development is the formation of the TE and ICM. The TE engages in implantation by directly interacting with the uterus and gives rise to tissues in the placenta. After implantation, 3 germ layers form from the ICM, which generates all the tissues in the animal body [18]. Although these modifications are caused by changes in Oct4/Cdx2 expression profiles, a major question is how the correct pluripotencyrelated genes kept active in the ICM are selectively inactivated upon switching to the tetraploid state through fusion at the 2-cell stage. In hatched tetraploid blastocysts, there were alterations in the metabolic processes and in protein localization and transport according to a cDNA microarray analysis [19]. To understand the mechanisms underlying early differentiation of tetraploid embryos during preimplantation development, we set out to compare the expression of multiple genes in tetraploid-, haploid- and diploidderived blastocysts. In this study, many differentially expressed genes were identified in the comparison between tetraploid- and haploid- or diploid-derived blastocyst embryos. 


\section{Materials and Methods}

\section{Animal ethics}

All animal experiments were approved and performed under the guidelines of the Konkuk University Animal Care and Experimentation Committee (IACUC approval number: KU11035).

\section{Electrofusion of diploid fertilized embryos}

Female ICR mice (aged, 8-10 weeks) were superovulated by the injection of $5 \mathrm{IU}$ of pregnant mare's serum gonadotropin (PMSG; Sigma-Aldrich, St. Louis, MO, USA), followed $48 \mathrm{~h}$ later by the injection of $5 \mathrm{IU}$ of hCG, and then mated with male ICR mice. Embryo collection was performed under a stereo microscope in Chatot, Ziomek, Bavister (CZB)-HEPES medium. The collected one-cell embryos were cultured in droplets of modified CZB medium under paraffin oil in plastic dishes at $37 \mathrm{C}$ in a $5 \% \mathrm{CO}_{2}$ incubator until reaching the 2-cell stage. To generate tetraploid embryos, the 2-cell stage embryos prepared by in-vitro culture were electrofused using an electro cell fusion generator (LF101; Nepa Gene, Chiba, Japan). The electrofusion solution was composed of $0.3 \mathrm{mM}$ mannitol, $0.1 \mathrm{mM} \mathrm{MgSO}_{4}$ and $0.05 \mathrm{mM} \mathrm{CaCl}_{2}$ supplemented with $0.01 \%$ bovine serum albumin (BSA) (w/v). Each group of $<20$ oocytes was transferred into $20 \mu \mathrm{l}$ of the electrofusion solution and positioned in a chamber between two parallel stainlesssteel electrodes. Fusion of 2-cell embryos was induced by a single pulse of 20 volts (AC) and 100 volts (DC) for $40 \mu \mathrm{sec}$ using an electro cell fusion generator (LF101; Nepa Gene, Chiba, Japan). For haploid embryos, one-cell embryos were collected from the oviducts of the female mice at $24 \mathrm{~h}$ after hCG injection and then activated using an electro cell fusion generator. Electrofused embryos were incubated for development in mCZB medium. The proportion of fused embryos was determined $2 \mathrm{~h}$ after the electrofusion procedure. The stages of tetraploid embryo development were evaluated under an inverted microscope at $24 \mathrm{~h}$ intervals.

\section{Assessment of Oct4 and Cdx2 expression during the preimplantation development of tetraploid embryos}

After washing twice with $\mathrm{Ca}^{2+}$ - and $\mathrm{Mg}^{2+}$-free Dulbecco's phosphate-buffered saline containing $0.1 \%$ polyvinyl alcohol (PBSPVA; Sigma-Aldrich, St. Louis, MO, USA), blastocyst-stage embryos were fixed for $30 \mathrm{~min}$ in PBS-PVA with $4 \%$ paraformaldehyde. The fixed embryos were then washed twice in PBS-PVA and stored overnight at $4 \mathrm{C}$ in PBS supplemented with $2 \%$ BSA (PBS-BSA; Sigma-Aldrich) and $0.1 \%$ Triton X-100 (Nacalai Tesque, Kyoto, Japan). To stain the TE and ICM, the samples were incubated for $90 \mathrm{~min}$ at room temperature in mouse anti- $C d x 2$ IgG (1:100 dilution; BioGenex), a TE marker, and rabbit anti-OCT4 IgG (POU domain, class 5 , transcription factor 1, also known as OCT3/4, 1:100 dilution; Santa Cruz Biotechnology, Santa Cruz, CA, USA), as an ICM marker. After the samples were washed twice in PBS-BSA, they were incubated with Alexa Fluor 568-labeled goat anti-mouse IgG and Alexa Fluor 488-labeled chicken anti-rabbit IgG antibodies (1:100 dilution; Molecular Probes, Eugene, OR, USA). After 3 washes of 10 min each in PBS-BSA, the DNA was stained for 30 min with $2 \mu \mathrm{g} / \mathrm{ml}$ 4',6-diamidino-2-phenylindole dihydrochloride (Molecular Probes). After the samples were thoroughly washed, they were mounted on slides using VECTASHIELD mounting medium (Vector Laboratories, Burlingame, CA, USA) and observed with an epifluorescence microscope. The processes of fixation and staining of samples were performed in 96-well culture dishes (STEMCELL Technologies, Vancouver, BC, Canada) and the samples were transferred for subsequent treatments by mouth pipette.

\section{Extraction and amplification of $m R N A$}

The mRNA from pools of $2 \mathrm{~N}$ and $4 \mathrm{~N}$ blastocysts was extracted using a Dynabeads mRNA Direct Kit (Invitrogen Dynal As, Oslo, Norway) according to the manufacturer's instructions. Due to the low concentrations of the extracted mRNAs, the integrity and purity of the preparations could not be verified. The mRNA from 3 pools of blastocysts ( $1 \mathrm{~N}, 2 \mathrm{~N}$ and $4 \mathrm{~N}$ ) was subjected to 2 rounds of linear amplification, and in vitro transcription was performed using a RiboAmp HS RNA Amplification Kit (Arcturus, Sunnyvale, Ca, USA) according to the manufacturer's instructions.

\section{Microarray analysis}

An Applied Biosystems Mouse Genome Survey Array (Applied Biosystems, Foster City, CA, USA) was used to analyze the transcriptional profiles of all samples according to the nucleic number of blastocysts. This array contains 32,996 60-mer oligonucleotide probes representing 32,381 individual mouse genes and $>3,000$ control probes. The microarray probes used were transcripts listed in the Celera Genomics Mouse Genome Database (http://www. celera.com, Celera Discovery System), RefSeq transcripts that were structurally created from the LocusLink public database (http:// ncbi.nlm.nih.bov/LocusLink/refseq.html), high-quality cDNA sequences from the Mammalian Gene Collection (MGC; http:// mgc.ncbi.nih.gov), and transcripts that had been experimentally validated at Applied Biosystems. Array hybridization, chemiluminescence detection, image acquisition and analysis were performed using an Applied Biosystems Chemiluminescence Detection Kit and an Applied Biosystems 1700 Chemiluminescent Microarray Analyzer, according to the manufacturer's protocol. The captured images were auto-gridded, and the chemiluminescent signals were quantified and corrected for background. Differences in microarray spot intensities were normalized. The Applied Biosystems Expression System software was used to extract the assay signal to noise ratio values from the microarray images. Bad spots flagged by the software $(>100)$ were removed from the analysis. To select differentially expressed genes, the remaining genes were further filtered using the Standard Expression Array System signal to noise threshold ( $\mathrm{S} / \mathrm{N}>3$ in at least 3 samples). The filtered genes were then normalized by the Lowess Regression normalization method. Genes with significantly different expression were identified using the 2-sample $t$-test $(\mathrm{P}<0.05)$ and the fold change method (Fold change $\geq 2$ ). Fold changes (tetraploid-derived blastocyst $v s$. diploid/ haploid derived blastocyst assay signal ratio) were calculated from the average intensities of each replicated sample. To minimize multiple testing problems, we performed Benjamini-Hochberg's FDR. Genes with significantly different expression were then categorized into particular functional categories using the Protein Analysis Through Evolutionary Relationships (Panther) classification system, which is a unique resource that classifies genes by 
Table 1. Primers and conditions used for real-time RT-PCR

\begin{tabular}{|c|c|c|c|c|}
\hline Primer name & Primer sequence & PCR conditions & Size (bp) & GenBank \\
\hline$\beta$-actin & $\begin{array}{l}\text { F: AGTGTGACGTTGACATCCGTA } \\
\text { R: GCCAGAGCAGTAATCTCCTTCT }\end{array}$ & $58 \mathrm{C}$ & 112 & NM007393 \\
\hline Oct4 & $\begin{array}{l}\text { F: CTCCCTACAGCAGATCACTCACA } \\
\text { R: AACCATACTCGAACCACATCCT }\end{array}$ & $63 \mathrm{C}$ & 220 & NM013633 \\
\hline Sox 2 & $\begin{array}{l}\text { F: CACAACTCGGAGATCAGCAA } \\
\text { R: CTCCGGGAAGCGTGTACTTA }\end{array}$ & $60 \mathrm{C}$ & 190 & NM011443 \\
\hline Klf4 & $\begin{array}{l}\text { F: CTGAACAGCAGGGACTGTCA } \\
\text { R: GTGTGGGTGGCTGTTCTTTT }\end{array}$ & $58 \mathrm{C}$ & 218 & NM010637 \\
\hline$C d x^{2}$ & $\begin{array}{l}\text { F: AGACAAATACCGGGTGGTGTA } \\
\text { R: CCAGCTCACTTTTCCTCCTGA }\end{array}$ & $60 \mathrm{C}$ & 153 & NM007673 \\
\hline Eomes & $\begin{array}{l}\text { F: GAGCTTCAACATAAACGGACTCAA } \\
\text { R: CGGCCAGAACCACTTCCA }\end{array}$ & $60 \mathrm{C}$ & 210 & NM01013 \\
\hline Krt8 & $\begin{array}{l}\text { F: ATCGAGATCACCACCTACCG } \\
\text { R: TGAAGCCAGGGCTAGTGAGT }\end{array}$ & $63 \mathrm{C}$ & 151 & NM03117 \\
\hline Vdac & $\begin{array}{l}\text { F: AATGACGGGACAGAGTTTGG } \\
\text { R: GGCTGACAACGTCAGTTTGA }\end{array}$ & $58 \mathrm{C}$ & 231 & NM011694 \\
\hline$W f d c 2$ & $\begin{array}{l}\text { F: TGCACTTTGGACAAGGACTG } \\
\text { R: ACACCTAAGCCTTCCCTGGT }\end{array}$ & $60 \mathrm{C}$ & 230 & NM02632 \\
\hline Tuft1 & $\begin{array}{l}\text { F: TCAGCGAGAAGCAGAACAGA } \\
\text { R: AAACCCAGCCACTTCCTTTT }\end{array}$ & $58 \mathrm{C}$ & 241 & NM011656 \\
\hline Lgals1 & $\begin{array}{l}\text { F: CATCACAGAGGTGTGCATC } \\
\text { R: AGGCCACGCACTTAATCTTG }\end{array}$ & $57 \mathrm{C}$ & 150 & NM008495 \\
\hline Gsta4 & $\begin{array}{l}\text { F: GCCAAGTACCCTTGGTTGAA } \\
\text { R: TTTTTCCTTGGGGGTTTT }\end{array}$ & $55 \mathrm{C}$ & 196 & NM01 \\
\hline Cyp2s 1 & $\begin{array}{l}\text { F: CCTCACCCACATAAGGTGCT } \\
\text { R: CCTGTCCTCACACCTGGAAT }\end{array}$ & $60 \mathrm{C}$ & 238 & AK054324 \\
\hline Chd8 & $\begin{array}{l}\text { F: ACAAATGACCCCTGAGTTGC } \\
\text { R: GGAGAGTCCCCATCTTCTCC }\end{array}$ & $60 \mathrm{C}$ & 228 & AK080266 \\
\hline Gzmn & $\begin{array}{l}\text { F: GCCAGTAGGAGATGGAGCAG } \\
\text { R: CCCCAGTGTGACTGTCATTG }\end{array}$ & $61 \mathrm{C}$ & 193 & NM153052.1 \\
\hline$L p p$ & $\begin{array}{l}\text { F: TACGGCATCCACATCTTCAA } \\
\text { R: ACCAACACAGGTTGGAGGAG }\end{array}$ & $58 \mathrm{C}$ & 178 & AK029335 \\
\hline Alx 3 & $\begin{array}{l}\text { F: AAACCCACTACCCTGACGTG } \\
\text { R: AGCTGAGGATGGCTGTCAGT }\end{array}$ & $60 \mathrm{C}$ & 205 & NM007441.2 \\
\hline
\end{tabular}

their function. In this system, published scientific experimental evidence and evolutionary relationships are used to predict function even in the absence of direct experimental evidence (https:// parther.appliedbiosystems.com).

\section{Real-time RT-PCR analysis}

Quantitative real-time RT-PCR reactions were performed using a kit from Bio-Rad (Munich, Germany) and the PCR reactions were conducted according to the manufacturer's instructions. The PCR involved an initial denaturation program (95 C for $10 \mathrm{~min}$ ), followed by 35 cycles of amplification and quantification $(95 \mathrm{C}$ for $10 \mathrm{sec}, 55 \mathrm{C} / 63 \mathrm{C}$ for $30 \mathrm{sec}$ and $72 \mathrm{C}$ for $30 \mathrm{sec}$, with a single fluorescence measurement). The primer sets for each gene amplified in the RT-PCR are shown in Table 1.

\section{Statistical analysis}

Each experiment was repeated at least three times to obtain
40-100 embryos per treatment. The data were subjected to arcsine transformation for each replication. The transformed values were analyzed using one-way ANOVA. $\mathrm{P}<0.05$ was defined as indicating statistical significance.

\section{Results}

Comparison of ICM- and TE-biomarker mRNA expression between tetraploid-and diploid-derived blastocysts

The relative abundance of ICM- and TE-related transcripts (Oct4, Sox 2 and K1f4 vs. Cdx2, Eomes and Krt8) was measured by realtime RT-PCR. Independent experiments $(n=6)$ using 10 embryos per group were carried out to yield quantitative data (Fig. 1). To normalize the RT-PCR reaction efficiency and to quantify ICMand TE-related mRNA, $\beta$-actin was used as an internal standard. After normalization with $\beta$-actin mRNA, the mRNA expression of ICM- and TE-related genes exhibited a distinct developmental 

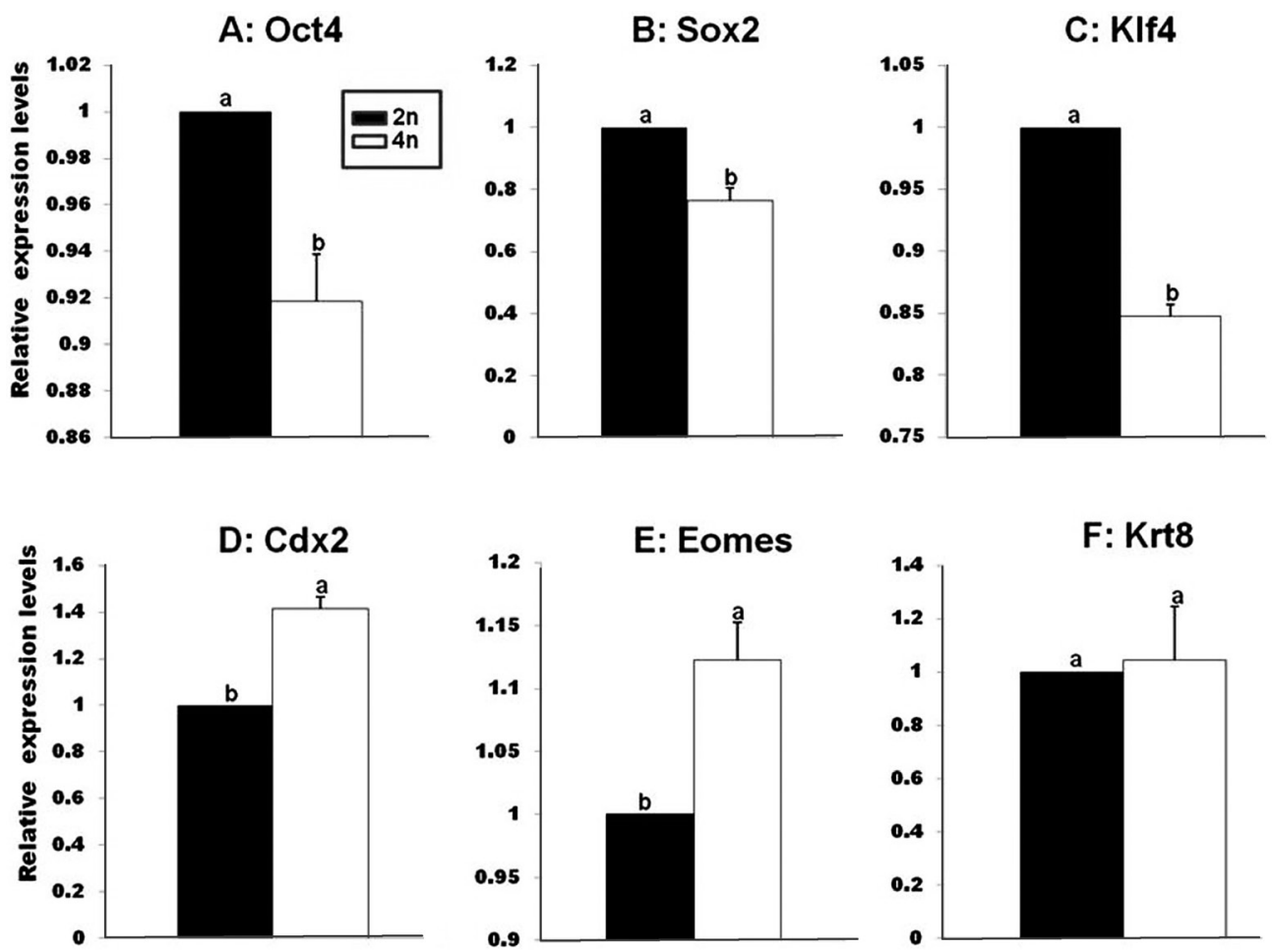

Fig. 1. Relative abundance of transcripts from 3 different inner cell mass-related genes, Oct4 (A), Sox2 (B) and Klf4 (C) and 3 different trophectoderm-related genes, Cdx2 (D), Eomes (E) and Krt8 (F), in mouse blastocysts derived from diploid (black) and tetraploid (white) embryos. mRNA from pools of 10 blastocyst-stage embryos was reverse transcribed and subjected to real-time quantitative PCR using transcript-specific primers (Table 1). All reactions were conducted in triplicate and normalized for $\beta$-actin mRNA expression. Data are presented as means \pm SEM (bars) from 3 determinations. Different superscripts $(a, b)$ indicate values with significant $(\mathrm{P}<0.05)$ differences in relative transcript abundance between diploid and tetraploid embryos at the blastocyst stage.

pattern: The expression levels of ICM markers such as Oct4, Sox2 and Klf4 in $4 \mathrm{n}$ blastocysts were significantly lower than in $2 \mathrm{n}$ blastocysts. In contrast, the induction of tetraploidy did not affect Krt8 mRNA expression but increased the expressions of Cdx 2 and Eomes at the blastocyst stage $(\mathrm{P}<0.05)$. This observation suggested that it is possible that the reduced number of ICM cells reflects the attenuated expressions of Oct4, K1f4 and Sox2.

\section{Allocation of inner cell mass (ICM) versus trophectoderm (TE) cells in tetraploid-derived blastocysts}

Three different types of blastocyst embryos were derived from diploid embryos: diploid embryos derived from normal fertilization with spermatozoa, haploid embryos derived by parthenogenetic activation of oocytes and tetraploid embryos produced by electrofusion. These blastocysts, produced by normal fertilization, parthenogenetic activation and electrofusion, were individually stained by a differential staining method and then evaluated for total cell number. The total cell numbers in tetraploid embryos $(29.3 \pm$ $4.41, \mathrm{n}=37$ ) were significantly lower than those in haploid-derived embryos $(127.6 \pm 3.15, \mathrm{n}=11)$ and in parthenogenetically-activated embryos $(89.8 \pm 1.74, \mathrm{n}=12)$. Furthermore, the tetraploid-derived blastocysts had fewer inner cell mass cells $(1.08 \pm 0.37)$ compared with haploid- (17.42 \pm 0.56$)$ and diploid-derived (35.82 \pm 1.58$) \mathrm{em}-$ bryos $(\mathrm{P}<0.05$; Table 2). Representative fluorescence micrographs of mouse-expanded blastocysts (Day 4) derived from diploid- and parthenote-derived embryos after differential staining are shown in Figs. 2A and 2B, respectively. Tetraploid-derived blastocysts differentially stained for ICM and TE nuclei were individually classified into 3 groups (group I, II and III : $0 \%, \sim 2-6 \%$ and $\sim 6-10 \%$, respectively) according to the number of Oct4-positive cells and these embryos were compared with haploid- and diploid-derived embryos. In the tetraploid-derived blastocysts, $70.27 \%(26 / 37)$ were allocated to group I whereas $21.62 \%(8 / 37)$ and $2.7 \%(1 / 37)$ were allocated to groups II and III, respectively (Figs. 2C-I, 2C-II and $2 \mathrm{C}$-III).

Genes differentially expressed between tetraploid-and diploidderived blastocysts

To evaluate the gene expression status at the blastocyst stage, we performed oligo microarray analysis of 300 blastocysts, including those derived from tetraploid $(n=100)$, parthenote $(n=100)$ and diploid $(n=100)$ blastocysts. This array contained 32,996 60-mer oligonucleotide probes representing 32,381 individual mouse genes and more than 3,000 control probes. Due to the low concentrations 
Table 2. Number of cells in tetraploid-, diploid- and haploid-derived blastocysts

\begin{tabular}{ccccc}
\hline $\begin{array}{c}\text { Ploidy of the } \\
\text { embryos }\end{array}$ & $\begin{array}{c}\text { No. of } \\
\text { blastocysts }\end{array}$ & $\begin{array}{c}\text { No. of total cells } \\
(\text { Mean } \pm \text { SE) }\end{array}$ & $\begin{array}{c}\text { No. of ICM cells } \\
(\text { Mean } \pm \text { SE) }\end{array}$ & $\begin{array}{c}\text { No. of TE cells } \\
(\text { Mean } \pm \text { SE) }\end{array}$ \\
\hline $1 \mathrm{~N}$ & 12 & $89.8 \pm 1.74^{\mathrm{b}}$ & $17.42 \pm 0.56^{\mathrm{b}}$ & $72.42 \pm 1.37^{\mathrm{b}}$ \\
$2 \mathrm{~N}$ & 11 & $127.6 \pm 3.15^{\mathrm{a}}$ & $35.82 \pm 1.58^{\mathrm{a}}$ & $91.73 \pm 2.39^{\mathrm{a}}$ \\
$4 \mathrm{~N}$ & 37 & $29.3 \pm 0.73^{\mathrm{c}}$ & $1.08 \pm 0.37^{\mathrm{c}}$ & $28.22 \pm 0.65^{\mathrm{c}}$ \\
\hline
\end{tabular}

a, b, c $\mathrm{P}<0.05$ : The means are significantly different. ICM, inner cell mass; TE, trophectoderm.
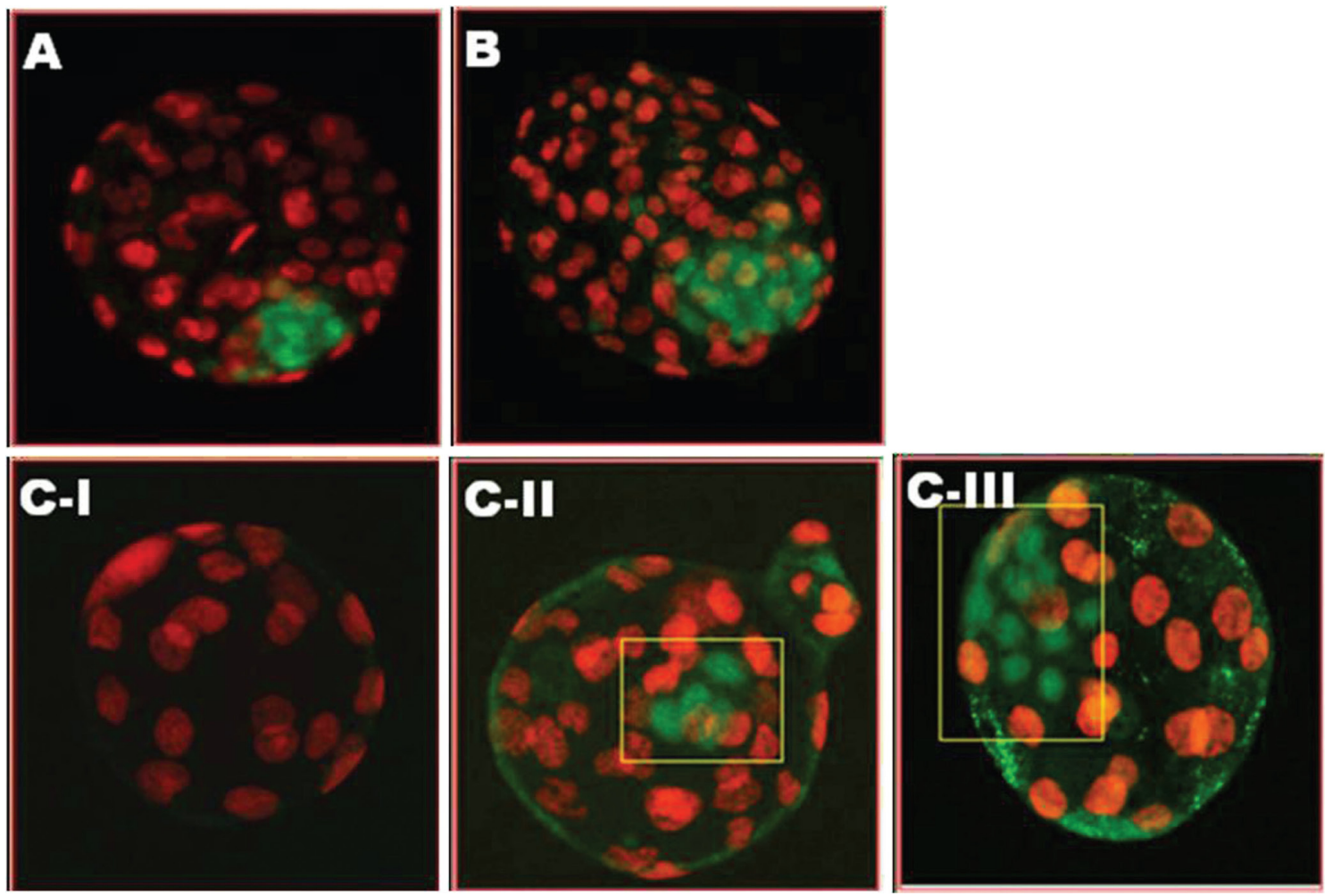

Fig. 2. Differential expression of Oct4 and Cdx2 in haploid (A), diploid (B) and induced tetraploid (C) embryos at the blastocyst stage. Tetraploid-derived blastocysts differentially stained for inner cell mass and trophectoderm nuclei were individually classified into 3 groups according to the number of Oct4-positive cells (C-I, C-II and C-III: $0 \%, \sim 2-6 \%$ and $\sim 6-10 \%$, respectively) and these embryos were compared with parthenote- and diploid-derived blastocysts.

of the extracted mRNAs, the integrity and purity of the preparations could not be verified. At the $\mathrm{P}<0.05$ level of significance, microarray analysis revealed that 50 genes were differentially expressed at the blastocyst stage in tetraploid vs. diploid or parthenote embryos. Of these 50 genes, 28 were more highly expressed in tetraploidderived blastocysts, whereas 22 were more highly expressed in diploid-derived blastocysts. Some of the genes were uncharacterized (unknown); we focused our attention on the known genes. Tables 3 and 4 show a list of the 50 genes with major variations observed upon comparison of the gene transcription in tetraploid blastocysts with that in diploid blastocysts. Even though data analysis using standard algorithms revealed no significant differences between the 2 groups, analyses of the common processes and gene pathways revealed that, overall, tetraploid embryos displayed upregulation of receptor activity, cell adhesion molecule activity and calcium ion binding activity, whereas protein biosynthesis, redox activity, transporter activity and transcription activity were significantly downregulated.

Our most interesting finding was that granzyme $\mathrm{N}$, heat shock protein 8 , aristaless-like homeobox 3, cytochrome P450 family 2 and cathepsin D were all significantly upregulated, whereas voltage-dependent anion channel 1 and glutathione S-transferase alpha 4 were significantly downregulated (Table 3 ), indicating that tetraploid-derived blastocysts were experiencing progressive cell death. Also, we observed the upregulation of jumonji $\mathrm{C}$ domaincontaining histone demethylase 1 , chromodomain helicase DNAbinding protein, and LIM domain-containing preferred translocation partner genes, which are involved in chromatin remodeling and the 
Table 3. Differentially expressed genes (DEGs) in the tetraploid blastocyst $(4 \mathrm{~N})$ compared with haploid (1N) or diploid $(2 \mathrm{~N})$ blastocysts $(\mathrm{P}<0.05)$

\begin{tabular}{|c|c|c|c|c|c|c|}
\hline & Gene symbol & Gene description & RefSeq & GO molecular function & $\begin{array}{c}\text { Fold } \\
(4 \mathrm{~N} / 2 \mathrm{~N})\end{array}$ & $\begin{array}{c}\text { Fold } \\
(4 \mathrm{~N} / 1 \mathrm{~N})\end{array}$ \\
\hline \multicolumn{7}{|c|}{ Genes with increased expression ( $>1.5$-fold $)$} \\
\hline 1 & Jhdmld & Jumonji $\mathrm{C}$ domain-containing histone demethylase 1 & NM_001033430 & Metal ion binding & 2.32 & 1.67 \\
\hline 2 & Aclp7 & Microtubule-actin crosslinking factor 1 & AK089453 & Actin binding & 1.92 & 1.51 \\
\hline 3 & Frmd4a & FERM domain containing 4A & NM_172475 & Binding & 1.60 & 1.55 \\
\hline 4 & Dsg3 & Desmoglein 3 & AK029018 & Calcium ion binding & 1.79 & 1.68 \\
\hline 5 & Spockl & $\begin{array}{l}\text { SPARC/osteonectin, CWCV and kazal-like domains } \\
\text { proteoglycan } 1\end{array}$ & AK049019 & Calcium ion binding & 1.63 & 1.61 \\
\hline 6 & Ccnd2 & Cyclin D2 & AK007904 & Cell cycle & 1.55 & 1.62 \\
\hline 7 & Sema $4 a$ & Sema domain, immunoglobulin domain (Ig) & NM_013658.2 & Cell differentiation & 1.51 & 1.51 \\
\hline 8 & Chd8 & Chromodomain helicase DNA binding protein 8 & AK080266 & Development & 1.85 & 1.63 \\
\hline 9 & Dpp4 & Dipeptidylpeptidase 4 & AK040409 & Peptidase activity & 1.97 & 1.63 \\
\hline 10 & Gzmn & Granzyme N & NM_153052.1 & Peptidase activity & 1.71 & 1.52 \\
\hline 11 & Ctsd & Cathepsin D & NM_009983.2 & Peptidase activity & 1.53 & 1.54 \\
\hline 12 & $H s p b 8$ & Heat shock protein 8 (Hspb8) & NM_030704.1 & Protein binding & 1.91 & 1.53 \\
\hline 13 & $L p p$ & LIM domain containing preferred translocation partner & AK029335 & Protein binding & 1.69 & 1.59 \\
\hline 14 & Slc20al & Solute carrier family 20, member 1 & AK084159 & Receptor activity & 1.83 & 1.62 \\
\hline 15 & $N d u f_{s} 1$ & NADH dehydrogenase (ubiquinone) Fe-S protein 1 & AK078590 & Redox activity & 1.92 & 1.58 \\
\hline 16 & Cyp2s1 & Cytochrome P450, family 2, subfamily s, polypeptide 1 & AK054324 & Redox activity & 1.59 & 1.57 \\
\hline 17 & Fusip1 & FUS interacting protein (serine-arginine rich) 1 & NM_010178.2 & RNA binding & 1.55 & 1.59 \\
\hline 18 & Mbtdl & MBT domain containing 1 & AK049518 & Transcription activity & 1.76 & 1.68 \\
\hline 19 & Alx3 & Aristaless-like homeobox 3 & NM_007441 & Transcription activity & 1.75 & 1.62 \\
\hline 20 & Flver 2 & Feline leukemia virus subgroup C cellular receptor family & NM_145447.2 & Transporter activity & 1.62 & 2.14 \\
\hline 21 & Hecw2 & HECT, $\mathrm{C} 2$ and WW domain-containing E3 ubiquitin ligase 2 & AK047602 & Ubiquitin-ligase activity & 1.79 & 1.57 \\
\hline 22 & 5330440M16Rik & Hypothetical protein & AK030640 & Unclassified & 2.16 & 1.83 \\
\hline 23 & $H 2-T 18$ & Histocompatibility 2 , T region locus 18 & AK039341 & Unclassified & 1.97 & 1.66 \\
\hline 24 & E030002K04Rik & Hypothetical protein & AK086813 & Unclassified & 1.87 & 1.66 \\
\hline 25 & B830005I23Rik & Hypothetical protein & AK046784 & Unclassified & 1.84 & 1.65 \\
\hline 26 & D930024N12Rik & Hypothetical protein & AK086384 & Unclassified & 1.84 & 1.51 \\
\hline 27 & Jakmip2 & Janus kinase and microtubule interacting protein 2 & AK076652 & Unclassified & 1.76 & 1.73 \\
\hline 28 & B930088G14Rik & Hypothetical protein & AK047561 & Unclassified & 1.64 & 1.66 \\
\hline
\end{tabular}

modulation of histone deacetylation in tetraploid embryos (Table 4).

\section{Validation of microarray data}

To verify the expression of the 10 genes identified from the microarray, we performed real-time RT-PCR using diploid- and tetraploid-derived blastocysts. Even though gene expression was slightly variable, particularly in the tetraploid embryos, five genes (VDAC, WFDC2, TUFT1, LGALS1 and GSTA4) were identified by the array data as being downregulated. As shown in Fig. 3A, the expression of these genes was reduced by approximately 20 to $40 \%$. In contrast, the expression levels of 5 other genes, CYP2S1, CHD8, GZMN, LPP and ALX3, were upregulated in the DNA chip array data; these genes were expressed at 1.2- to 1.8-fold higher levels in tetraploid blastocysts than in the controls (Fig. 3B).

\section{Discussion}

The present experiment was conducted to examine how many tetraploid-derived blastocyst embryos have Oct4-positive cells, which indicate inner cell mass status. At the early blastocyst stage,
Oct4 staining began to decrease in a few TE cells (peripheral cell nuclei) but was still detectable in both TE and ICM cells. However, at the expanded blastocyst stage, Oct4 was localized only in the ICM nuclei and was largely absent from the nuclei of the TE. In tetraploid embryos, Cdx2-positive nuclei were first detected at the late compaction stage, with greatly increased $\mathrm{Cdx} 2$ expression at the blastocyst and expanded blastocyst stages, whereas Oct4 expression had disappeared by the time tetraploid embryos reached the expanded blastocyst stage [20].

During the fourth or fifth cleavage division of mouse embryos, preimplantation embryos form the ICM from inner apolar cells and the TE from outer polar cells. Prospective ICM and TE cells express Oct4 and Cdx2, respectively [21]. In mid-blastocyst stages, Oct4-positive cells randomly appear within the ICM, whereas Cdx2-positive cells are localized to the outer surface of the ICM. As we previously reported [20], Oct4 expression from the 2-cell to the morula stage was similar in tetraploid and diploid embryos. Interestingly, we discovered that at the expanded blastocyst stage, Oct4 expression had disappeared in most of the tetraploid-derived embryonic cells, though some embryonic cells at the ICM site 
Table 4. Differentially expressed genes (DEGs) in the tetraploid blastocyst (4N) compared with haploid (1N) or diploid $(2 \mathrm{~N})$ blastocysts $(\mathrm{P}<0.05)$

\begin{tabular}{|c|c|c|c|c|c|c|}
\hline & Gene symbol & Gene description & RefSeq & $\begin{array}{l}\text { GO molecular } \\
\text { function }\end{array}$ & $\begin{array}{l}\text { Fold } \\
(4 \mathrm{~N} / 2 \mathrm{~N})\end{array}$ & $\begin{array}{l}\text { Fold } \\
(4 \mathrm{~N} / 1 \mathrm{~N})\end{array}$ \\
\hline \multicolumn{7}{|c|}{ Genes with decreased expression $(<-1.5$-fold $)$} \\
\hline 1 & $D b i$ & Diazepam binding inhibitor, transcript variant 2 & NM_007830.3 & Acyl-CoA binding & -1.62 & -1.59 \\
\hline 2 & Atplal & ATPase, $\mathrm{Na}^{+} / \mathrm{K}^{+}$transporting, alpha 1 polypeptide & NM_144900.1 & ATPase activity & -1.55 & -1.69 \\
\hline 3 & Vdacl & Voltage-dependent anion channel 1 & NM_011694.3 & Ion channel & -1.80 & -1.59 \\
\hline 4 & Tpil & Triosephosphate isomerase 1 & NM_009415.1 & Isomerase activity & -1.52 & -2.00 \\
\hline 5 & Fabp3 & Fatty acid binding protein 3 , muscle and heart & NM_010174.1 & Lipid binding & -1.75 & -1.51 \\
\hline 6 & Bat1a & HLA-B-associated transcript $1 \mathrm{~A}$ & NM_019693.2 & Nucleic acid binding & -1.76 & -1.56 \\
\hline 7 & Xpnpep 1 & X-prolyl aminopeptidase (aminopeptidase P) 1 & NM_133216.2 & Peptidase activity & -1.97 & -1.57 \\
\hline 8 & $W f d c 2$ & WAP four-disulfide core domain 2 & NM_026323.2 & Protease inhibitor & -2.23 & -1.71 \\
\hline 9 & Spint1 & Serine protease inhibitor, Kunitz type 1 & NM_016907.3 & Protease inhibitor & -1.75 & -1.58 \\
\hline 10 & Snx17 & Sorting nexin 17 & NM_153680.2 & Protein binding & -1.76 & -1.54 \\
\hline 11 & Tuft1 & Tuftelin 1 & NM_011656.2 & Protein binding & -2.08 & -1.53 \\
\hline 12 & $Z y x$ & Zyxin & NM_011777.2 & Protein binding & -1.86 & -1.79 \\
\hline 13 & EG668829 & Similar to ribosomal protein L24 & XM_001005405.1 & Ribosomal protein & -2.14 & -1.56 \\
\hline 14 & Mrpl17 & Mitochondrial ribosomal protein L17 & NM_025301.2 & Ribosomal protein & -1.96 & -1.53 \\
\hline 15 & EG622236 & Predicted gene, EG622236, transcript variant 1 & XM_917756.3 & Ribosomal protein & -1.86 & -1.78 \\
\hline 16 & Rpl23 & Ribosomal protein L23 & NM_022891.2 & Ribosomal protein & -1.91 & -1.62 \\
\hline 17 & Rpl32 & Ribosomal protein L32 & NM_172086.2 & Ribosomal protein & -1.70 & -1.52 \\
\hline 18 & LOC100044425 & Similar to ribosomal protein $\mathrm{L} 36 \mathrm{a}$ & XM_001472147.1 & Ribosomal protein & -1.95 & -1.58 \\
\hline 19 & Lgals1 & Lectin, galactose binding, soluble 1 & NM_008495.2 & Sugar binding & -2.48 & -2.18 \\
\hline 20 & Klf5 & Krüppel-like factor 5 & NM_009769.4 & Transcription factor & -1.69 & -1.50 \\
\hline 21 & Gsta4 & Glutathione S-transferase, alpha 4 & NM_010357.1 & Antioxidant activity & -1.71 & -1.74 \\
\hline 22 & Gars & Glycyl-tRNA synthetase & NM_180678.3 & tRNA ligase activity & -1.59 & -1.95 \\
\hline
\end{tabular}

did remain Oct4-positive. Previously, we reported that $83 \%$ of the tetraploid-derived blastocysts had 80 chromosomes, and $17 \%$ exhibited mixploidy [20], indicating a close relationship between the numbers of tetraploid-derived blastocysts with Oct4-positive cells and aberrant chromosome numbers. We also demonstrated that the transcription levels of ICM-related genes such as Oct4, Sox 2 and Klf4 were 0.1 -fold lower in tetraploid-derived blastocysts compared with diploid blastocysts $(\mathrm{P}<0.05)$. Therefore, the question becomes one of how the ICM can inhibit transcription and translation of these genes (Oct4, Sox 2 and K1f4), which are abundantly expressed in tetraploid-derived blastocysts.

To understand the mechanisms that reverse silencing or induce activation in ICM lineages as a result of tetraploid induction during transdifferentiation, we investigated genome-wide gene expression using a DNA chip. In this study, granzyme N, heat shock protein 8 , aristaless-like homeobox 3, cytochrome P450 family 2 and cathepsin D were significantly upregulated in tetraploid-derived blastocysts, whereas voltage-dependent anion channel 1 and glutathione S-transferase alpha 4 were significantly downregulated. It is wellknown that aristaless-like homeobox 3-deficient embryos show increased apoptosis, and morphometric analysis has indicated that such embryos are, on average, of smaller size than islets from control mice. Also, voltage-dependent anion channel 1 has been implicated in apoptosis, as it forms an open pore that allows the release of cytochrome $c$ (cyto $c$ ) and other proteins from the mitochondrial intermembrane space into the cytosol. In addition, "death" receptors [tumor necrosis factor receptor 1
(TNFR1)/Fas] engage caspase 8 , whereas various stress conditions induce calpain, caspases, cathepsins or granzyme B to cleave and activate BID, which is a proapoptotic BH3-only BCL2 family member [22]. Depletion of endogenous zyxin, which colocalizes with HIPK 2 at the cytoskeleton and in the cell nucleus, stimulates proteasome-dependent HIPK 2 degradation. Also, it is wellknown that cathepsin D is a very good marker for areas of embryonic cell death [23]. As implied in the above discussion, the compromised ICM seen in tetraploid blastocysts may be caused by an increase in apoptotic protein expression as well as a dose-dependent loss of expression of ICM-related genes such as Oct4, Sox2 and K1f4.

Previously, Kawaguchi et al. (2009) reported the profiling of global gene expression using microarray analysis to identify molecular and cellular pathways that were affected by tetraploid and diploid hatched blastocysts of mice. However, in this study, we compared gene expression profiles of the tetraploid blastocyst with those of parthenote- and diploid-derived blastocysts [19]. As a result of differences in the methods of statistical analysis, Kawaguchi's group may have found that genes involved in cell division and the cell cycle in tetraploid blastocysts were mainly downregulated, whereas the present study showed that the main differential expressions among tetraploid-, parthenote- and diploidderived blastocysts involved apoptosis-related genes. Therefore, this discrepancy may be caused by 2 reasons, 1) comparison of diploid and tetraploid blastocysts vs. parthenote, diploid and tetraploid blastocysts and 2) the blastocyst stages used, such as hatched vs. middle blastocyst stages. 


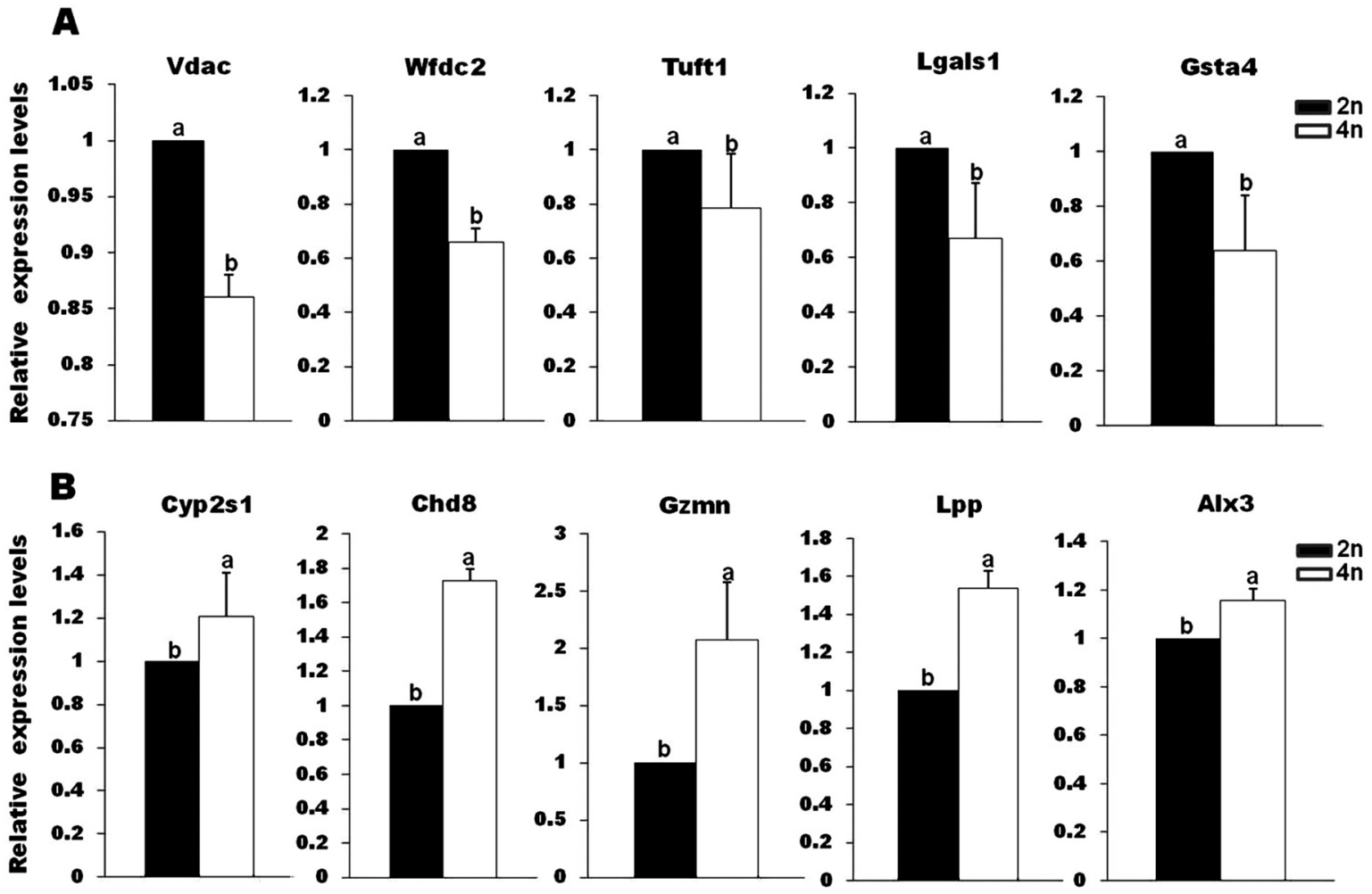

Fig. 3. Validation of DNA chip data by real-time RT-PCR analysis. mRNA from pools of 10 embryos at the blastocyst stage was reverse transcribed and subjected to real-time quantitative PCR using transcript-specific primers (Table 1). All reactions were conducted in triplicate and normalized for $\beta$-actin mRNA expression. Data are presented as means \pm SEM (bars) from 3 determinations. Different superscripts $(a, b)$ indicate values with significant $(\mathrm{P}<0.05)$ differences in relative transcript abundance between diploid and tetraploid embryos at the blastocyst stage. All RT-PCR data examined in this study mirror DNA chip data, with increases or decreases in the tetraploid-derived blastocyst as compared with the diploid-derived blastocyst. Data represent values from 3 independent experiments.

Mouse Jmjd1c mRNA is expressed in the fertilized egg, blastocyst, undifferentiated embryonic stem cells, embryonic germ cells, c-Kit+/Sca-1+/Lin- hematopoietic stem cells and other tissues, indicating that POU5F1-mediated expression of JMJD1C histone demethylase is implicated in the reactivation of silenced genes in undifferentiated ES cells [24]. In this study, however, JMJD1C mRNA expression in tetraploid embryos was significantly increased. This is especially intriguing in the context of tetraploid-derived blastocysts because tetraploid blastocysts have a compromised inner cell mass. We also observed the upregulation of chromodomain helicase DNA-binding protein (CHD). CHD is known to affect transcription through its ability to remodel chromatin and modulate histone deacetylation. Notably, earlier studies have shown the importance of differentiation and cell type-specific transcriptional programming during the terminal differentiation of hematopoietic cells [25]. Therefore, these observations suggest that the JmjC domain and CHD play pivotal roles in trophoblast differentiation in the absence of the ICM.

The microarray-based genomic survey is a high throughput approach that allows parallel study of the expression patterns of thousands of genes [26]. In this study, we discovered previously unknown gene expression patterns related to tetraploid-derived blastocysts. In agreement with the phenotypic alterations found in tetraploid-derived blastocysts, many differentially expressed genes were shared between the gene lists for diploid- and parthenotederived blastocysts, suggesting that common pathways are affected by the technique and culture system used. However, the numerous unique gene functions and pathways affected solely in tetraploidderived blastocysts imply that many of these unique genes are good candidates for studying blastocysts with compromised ICMs.

\section{Acknowledgments}

This work was partially supported by Woo Jang-Choon (PJ007849) projects from the RDA, Republic of Korea. We thank Dr P Hughes (BioEdit) for assistance with the manuscript preparation.

\section{References}

1. Nagy A, Gócza E, Diaz EM, Prideaux VR, Iványi E, Markkula M, Rossant J. Embryonic stem cells alone are able to support fetal development in the mouse. Development 1990; 110: 815-821. [Medline]

2. Eakin GS, Behringer RR. Tetraploid development in the mouse. Dev Dyn 2003; 228 
751-766. [Medline] [CrossRef]

3. Eakin GS, Hadjantonakis AK, Papaioannou VE, Behringer RR. Developmental potential and behavior of tetraploid cells in the mouse embryo. Dev Biol 2005; 288: 150-159. [Medline] [CrossRef]

4. Li J, Ishii T, Wen D, Mombaerts P. Non-equivalence of cloned and clonal mice. Current Biol 2005; 15: R756-757. [CrossRef]

5. Modliński JA. Preimplantation development of microsurgically obtained haploid and homozygous diploid mouse embryos and effects of pretreatment with Cytochalasin B on enucleated eggs. J Embryol Exp Morphol 1980; 60: 153-161. [Medline]

6. Modlinski JA. The fate of inner cell mass and trophectoderm nuclei transplanted to fertilized mouse eggs. Nature 1981; 292: 342-343. [Medline] [CrossRef]

7. Snow MH. Tetraploid mouse embryos produced by cytochalasin B during cleavage. Nature 1973; 244: 513-515. [Medline] [CrossRef]

8. Tarkowski AK, Witkowska A, Opas J. Development of cytochalasin in B-induced tetraploid and diploid/tetraploid mosaic mouse embryos. J Embryol Exp Morphol 1977; 41: 47-64. [Medline]

9. Niemierko A, Opas J. Manipulation of ploidy in the mouse. In: Daniel J Jr. (ed), Methods in Mammalian Reproduction. New York: Academic Press; 1978: 49-65.

10. Sencia M, Takeda J, Abe S, Nakamura T. Induction of cell fusion of plant protoplasts by electric stimulation. Plant Cell Physiol 1979; 20: 1441-1443.

11. Berg H. Biological implications of electric field effects. Part V. Fusion of blastomeres and blastocysts of mouse embryos. Bioelectrochem Bioenerg 1982; 9: 223-228. [CrossRef]

12. Kurischko A, Berg H. Electro-fusion of rat and mouse blastomeres. Bioelectrochem Bioenerg 1986; 15: 513-519. [CrossRef]

13. Kubiak JZ, Tarkowski AK. Electro-fusion of mouse blastomeres. Exp Cell Res 1985; 157: 561-566. [Medline] [CrossRef]

14. Ozil JP, Modlinski JA. Effects of electric field on fusion rate and survival of 2-cell rabbit embryos. J Embryol Exp Morphol 1986; 96: 211-228. [Medline]

15. Capecchi MR. The new mouse genetics: altering the genome by gene targeting. Trends Genet 1989; 5: 70-76. [Medline] [CrossRef]

16. Nagy A, Rossant J, Nagy R, Abramow-Newerly W, Roder JC. Derivation of completely cell culture-derived mice from early-passage embryonic stem cells. Proc Natl
Acad Sci USA 1993; 90: 8424-8428. [Medline] [CrossRef]

17. Parker-Thornburg JV, Alana JL, Smith CN, Detry M, Rojas ML, Baskin KK Cryopreserved morulae can be used to efficiently generate germline-transmitting chimeras by blastocyst injection. Transgenic Res 2005; 14: 685-690. [Medline] [CrossRef]

18. Marikawa Y, Alarcon VB. Establishment of trophectoderm and inner cell mass lineages in the mouse embryo. Mol Reprod Dev 2009; 76: 1019-1032. [Medline] [CrossRef]

19. Kawaguchi J, Kano K, Naito K. Expression profiling of tetraploid mouse embryos in the developmental stages using a cDNA microarray analysis. J Reprod Dev 2009; 55: 670-675. [Medline] [CrossRef]

20. Park MR, Lee AR, Bui HT, Park C, Park KK, Cho SG, Song H, Kim JH, Van Thuan N, Kim JH. Chromosome remodeling and differentiation of tetraploid embryos during preimplantation development. Dev Dyn 2011; 240: 1660-1669. [Medline] [CrossRef]

21. Lin SC, Wani MA, Whitsett JA, Wells JM. Klf5 regulates lineage formation in the pre-implantation mouse embryo. Development 2010; 137: 3953-3963. [Medline] [CrossRef]

22. Yin D, Zhang Y, Stuart C, Miao J, Zhang Y, Li C, Zeng X, Hanley G, Moorman J, Yao Z, Woodruff M. Chronic restraint stress modulates expression of genes in murine spleen. J Neuroimmunol 2006; 177: 11-17. [Medline] [CrossRef]

23. Crone J, Glas C, Schultheiss K, Moehlenbrink J, Krieghoff-Henning E, Hofmann TG. Zyxin is a critical regulator of the apoptotic HIPK2-p53 signaling axis. Cancer Res 2011; 71: 2350-2359. [Medline] [CrossRef]

24. Katoh M, Katoh M. Comparative integromics on JMJD1C gene encoding histone demethylase: Conserved POU5F1 binding site elucidating mechanism of JMJD1C expression in undifferentiated ES cells and diffuse-type gastric cancer. Int J Oncol 2007; 31: 219-223. [Medline]

25. Heyworth C, Pearson S, May G, Enver T. Transcription factor-mediated lineage switching reveals plasticity in primary committed progenitor cells. EMBO J 2002; 21: 3770-3781. [Medline] [CrossRef]

26. Lipshutz RJ, Fodor SP, Gingeras TR, Lockhart DJ. High density synthetic oligonucleotide arrays. Nat Genet 1999; 21: 20-24. [Medline] [CrossRef] 